\title{
Addressing A Compensation Anomaly In An Academic Setting
}

Michael C. Budden, Southeastern Louisiana University, USA Robert Cope, Southeastern Louisiana University, USA Yu Hsing, Southeastern Louisiana University, USA

\begin{abstract}
Faculty compensation is a serious matter. Rewards for performance are an expectation. Managers recognize that rewards often drive performance and productivity. Faculty members who perform well expect to be rewarded well. Faculty members expend considerable time and effort developing evaluation instruments and procedures for assessing and rewarding peer performance. Depending on how the reward process is implemented faculty performance rewards may not result as expected. This paper contrasts faculty compensation models including one that produces a high performance, low compensation anomaly for higher paid faculty.
\end{abstract}

Keywords: compensation, performance, assessment, reward, anomaly

\section{INTRODUCTION}

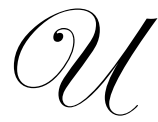

niversity faculty members usually are aware of the compensation/performance practices and expectations of their employers. Faculty members who perform well generally expect to be rewarded well. Similarly, faculty members who perform poorly may recognize that their performance may not result in an improved compensation level. Feedback on performance can and does impact resulting performance levels.

Performance-related feedback has been described as a primary mechanism for enhancing both individual performance and motivation (Ilgen, Fisher and Taylor 1979). Feedback can be used to motivate employee efforts to organizational success (Larson, 1984). Bannister (1986) also found that feedback was a useful tool for motivating performance when it provides employees with information that is important to accomplishing their own goals. As feedback is an important component in for-profit businesses, it is important in academic settings as well.

Several researchers (Bennett 1985, Bennett and Chater 1984, Reisman 1986) emphasize the importance of feedback in academic settings. Performance feedback from academic administrators has been assumed to motivate faculty to achieve higher levels of performance (Bennett 1985). However, results reported by Landy, Barnes and Murphy (1978) and Greenberg (1986) indicate the supervisor's knowledge of the subordinate's performance was related to perceptions of fairness and accuracy of the performance appraisal. Ilgen et. al (1981) find trust in one's supervisor is related to favorable perceptions of the appraisal atmosphere and helpfulness of the feedback. Similarly, Fulk, Brief and Barr (1985) note that trust in one's supervisor was related to perceptions of fairness and accuracy of the performance appraisal. Still, pay for performance is usually expected. Mathis and Jackson (2006, p. 374) proffer that people in organizations work in order to gain rewards for their efforts and the extent to which they feel they have been fairly compensated affects their performance.

Daft (2005, p. 454) notes that pay for performance aligns behaviors needed to help the organization achieve it strategic goals and provides employees incentives to make the firm more efficient. Williams (2007, p. 376) encourages companies to analyze employee turnover to determine whether good or poor performers are choosing to leave the company. Goodson, Duarte and Budden (1995) note that perceptions of supervisor credibility can demotivate faculty members. If good performers are leaving and poor performers are staying, compensation may be 
part of the culprit. Williams (2007) mentions that poor performers are more likely to stay when they are paid large, guaranteed salaries. The thought of poor performers staying does not sit well with many.

The question as to appropriate compensation is critical. As faculty members are well aware, compensation serves as a main attractant to a position. Lussier (2006, p. 284) mentions that compensation serves to attract and retain employees. Similarly, Bateman and Snell (2009, p. 378) mention that reward systems can serve the purpose of attracting, motivating and retaining people. George and Jones (2005, p. 90) mention that high job satisfaction leads to lower employee turnover. So, where does this leave faculty?

Faculty members have long recognized that there is difficulty in providing assessment instruments for their activities. Discussions abound about how to measure teaching effectiveness. Questions arise as to how to value publications and service activities. And in the end, the question as to adequate compensation for performance enters the picture.

\section{THE ANOMALY}

Assume a department exists that has only four faculty members. The four faculty members' performances are assessed annually. They have different ranks, were hired at different times, and have different salaries as indicated. Still, there is one merit instrument for evaluating performance. That instrument is a rating scale that provides a point total (from 0 to 100 points). Thus each of the faculty and their annual evaluations are shown in Table 1. Note, the instrument allows up to 10 "bonus" points to be earned for exemplary accomplishments, thus a 110 is possible.

Table 1

\begin{tabular}{|c|c|c|c|}
\hline Faculty Member & Annual Salary \$ & Annual Evaluation Points & University Set-Aside \$ (7.5\%) \\
\hline 1 & 100,000 & 110 & 7,500 \\
\hline 2 & 85,000 & 100 & 6,375 \\
\hline 3 & 70,000 & 80 & 5,250 \\
\hline 4 & 50,000 & 70 & 3,750 \\
\hline Total & & & 22,875 \\
\hline
\end{tabular}

The University provides the department with a $7.5 \%$ fund to distribute merit-based raises. The distribution of the funds is not mandated explicitly, but it is expected that performance will be rewarded in an equitable manner.

One method for dividing the funds is to divide each individual's point total by the department's total annual points earned to derive a weighting scale that would then be used to distribute the funds. Table 2 indicates such a point weighting scale. Note that this results in an equal dollar value per assessment point. In other words, all faculty accomplishments are rewarded equally, regardless of salary level.

Table 2

\begin{tabular}{|c|c|c|c|}
\hline Faculty Member & $\begin{array}{c}\text { Total Points / Individual } \\
\text { Points }\end{array}$ & $\begin{array}{c}\text { Percentage of total points } \\
\text { earned }\end{array}$ & $\begin{array}{c}\text { Column 3 x University Set- } \\
\text { aside }\end{array}$ \\
\hline 1 & $110 / 360$ & 30.55 & 6,989 \\
\hline 2 & $100 / 360$ & 27.77 & 6,354 \\
\hline 3 & $80 / 360$ & 22.22 & 5,083 \\
\hline 4 & $70 / 360$ & 19.44 & 4,448 \\
\hline
\end{tabular}

Thus, faculty raise percentages would appear as follows: 
Table 3

\begin{tabular}{|c|c|c|}
\hline Faculty Member (salary) & \$ Pay raise & \% Increase \\
\hline $1(\$ 100,000)$ & 6,989 & 7.98 \\
\hline $2(\$ 85,000)$ & 6,354 & 7.47 \\
\hline $3(\$ 70,000)$ & 5,083 & 8.89 \\
\hline
\end{tabular}

Thus, the faculty member with the lowest annual performance evaluation receives the highest percentage increase in pay of 8.89 percent. That is well above the University's set aside fund of 7.5 percent. Indeed, the highest performing faculty member with a $110 \%$ assessment receives less than the average increase; earning only a 6.98 percent raise. The fact that the best performing faculty member receives the lowest percentage raise while the lowest performing faculty member receives the largest percentage raise is an anomaly of the process. It is noted that such an anomaly rewards faculty member \#1 with a larger dollar raise than the others while providing a lower percentage raise. Indeed, one may interpret Table 3's third column as indicating that only one faculty member exceeded the average raise set aside of $7.5 \%$, and that faculty member's actual performance assessment was the lowest of the four.

If the University were to require a flat, across-the-board raise of a certain amount, then the anomaly becomes more pronounced. For example, if the University mandates an across the board distribution of $\$ 400$ per faculty member before the merit distribution, then the result would be as shown in Table 4 .

Table 4

\begin{tabular}{|c|c|c|c|c|c|}
\hline $\begin{array}{c}\text { Faculty } \\
\text { Member }\end{array}$ & $\begin{array}{c}\text { Total Points / } \\
\text { Individual } \\
\text { Points }\end{array}$ & $\begin{array}{c}\text { Percentage of } \\
\text { total points } \\
\text { earned }\end{array}$ & $\begin{array}{c}\text { \$ Across the } \\
\text { Board }\end{array}$ & $\begin{array}{c}\text { Column 3 x University Set-aside } \\
\text { of \$21,275 (\$22,875 less \$1600 } \\
\text { across the board distribution) }\end{array}$ & $\begin{array}{c}\text { Final \$ Raise } \\
(\%)\end{array}$ \\
\hline 1 & $110 / 360$ & 30.56 & 400 & 6,499 & $6,899(6.89 \%)$ \\
\hline 2 & $100 / 360$ & 27.77 & 400 & 5,908 & $6,308(7.42 \%)$ \\
\hline 3 & $80 / 360$ & 22.22 & 400 & 4,727 & $5,127(7.32 \%)$ \\
\hline 4 & $70 / 360$ & 19.44 & 400 & 4,135 & $4,535(9.07 \%)$ \\
\hline & & & 1,600 & 21,269 (rounding) & \\
\hline
\end{tabular}

The result of mandating an across-the-board raise of a fixed amount ( $\$ 400$ in this example) before the distribution of merit funds exacerbates the anomaly in the sense that the lowest performing faculty member actually increases their raise. Conversely, the highest performing faculty member's raise falls from 6.98 percent to 6.89 percent. Again, it should be pointed out that the dollar raise is highest for the highest paid faculty member, but the percentage increase lags. Indeed, one may interpret the less than average raise of faculty member \#1 as an indication that the faculty member is not performing at an adequate level of performance (less than average) - which would be in error.

It is interesting to note that a potential interpretation of the anomaly's impact is that it is better to have two lower paid faculty members with less than maximum ratings than one higher paid faculty with a stellar rating, if the goal of the unit is to increase overall productivity alone. In other words, two $\$ 50,000$ salaried faculty members each receiving a 70 on the rating scale, ostensibly would produce more output than one $\$ 100,000$ faculty member with a rating of 110 .

An interesting twist on the pay raise anomaly occurs if merit points were reversed for the four faculty members. If the lowest paid faculty member were to receive the best merit evaluation, and the highest paid faculty member were to receive the lowest merit score, the results appear incongruous. If no across the board raise is implemented, then Table 5 displays the results of such an incongruity. 
Table 5

\begin{tabular}{|c|c|c|c|c|c|}
\hline Faculty Member & $\begin{array}{c}\text { Total Points / } \\
\text { Individual Points }\end{array}$ & $\begin{array}{c}\text { Percentage of } \\
\text { total points } \\
\text { earned }\end{array}$ & $\begin{array}{c}\text { \$ Raise based on } \\
\text { Merit Weight }\end{array}$ & \$ per Merit Point & $\begin{array}{c}\text { Raise } \\
\text { Percentage }\end{array}$ \\
\hline 1 & $70 / 360$ & 19.44 & $\$ 4,447$ & 63.54 & $4.45 \%$ \\
\hline 2 & $80 / 360$ & 22.22 & $\$ 5,083$ & 63.54 & $5.98 \%$ \\
\hline 3 & $100 / 360$ & 27.78 & $\$ 6,354$ & 63.54 & $9.08 \%$ \\
\hline 4 & $110 / 360$ & 30.56 & $\$ 6,989$ & 63.54 & $13.98 \%$ \\
\hline
\end{tabular}

As can be seen in Table 5, the anomaly results in the lowest paid faculty member increasing his/her take (now 13.98\%), while the highest paid faculty member decreases his/her take, both in dollars and as a percentage.

The distribution of funds in this case is not the only method of distributing pay raise monies. In a convenience sampling of five administrators at 3 different universities, most differed in their calculation of raises given the basic information in Table 1. It is just this difference that creates much discussion in higher education circles as to how to assess and reward faculty performance.

One method of reducing or eliminating the anomaly involves weighting both the merit points and the salaries. Such a weighting creates a situation whereby the person with the highest merit evaluation and highest salary receives both the highest dollar raise and the highest percentage raise. That case is demonstrated in Table 6 .

Table 6

\begin{tabular}{|c|c|c|c|c|c|}
\hline Faculty Member & $\begin{array}{c}\text { Total Points / } \\
\text { Individual Points }\end{array}$ & $\begin{array}{c}\text { Percentage of } \\
\text { total points } \\
\text { earned }\end{array}$ & $\begin{array}{c}\text { \$ Raise based on } \\
\text { Merit Weight }\end{array}$ & \$ per Merit Point & $\begin{array}{c}\text { Total Raise } \\
\text { Percent }\end{array}$ \\
\hline 1 & $110 / 360$ & 19.44 & $\$ 8,798$ & 79.98 & $8.80 \%$ \\
\hline 2 & $100 / 360$ & 22.22 & $\$ 6,799$ & 67.99 & $8.00 \%$ \\
\hline 3 & $80 / 360$ & 27.78 & $\$ 4,479$ & 55.99 & $6.40 \%$ \\
\hline 4 & $70 / 360$ & 30.56 & $\$ 2,799$ & 39.99 & $5.60 \%$ \\
\hline & & $\begin{array}{c}\$ 22,879 \\
\text { (rounding) }\end{array}$ & & \\
\hline
\end{tabular}

By using a method that weights both salary and merit points the anomaly does not occur. What some would expect - a higher salary and a higher merit assessment results in a higher raise and raise percentage - actually occurs. A lower performance assessment results in lower percentage raise and a lower dollar increase. However, this method also presents a conundrum in the dollar per point values differ for similar levels of productivity.

\section{SUMMARY}

Rewarding faculty for their performance is always a touchy subject. The fact that much of what faculty members do is difficult to assess creates much discussion in academic circles. The occurrence of a compensation anomaly in some pay raise processes creates room for dissension among faculty ranks. Both methods discussed have their attractive points and their detriments.

In the method that creates the anomaly, all merit points have an equal value. One may argue that since faculty have the same performance expectations that all performance points be valued equally. On the other hand, one may argue that a person who has performed better should be rewarded in such a manner that recognizes differences in salary, and in the contribution that results from salary differences to the overall pay raise fund. The differences that result from various methods of weighting will continue to generate discussions in faculty circles. 


\section{AUTHOR INFORMATION}

Dr. Michael C. Budden is the Mayfield Professor of Marketing at Southeastern Louisiana University. With 20 years of university administrative experience, Dr. Budden's research interests lie in ethics, marketing law and issues of faculty performance.

Dr. Robert Cope is Interim Head of the Marketing and Finance Department at Southeastern Louisiana University. His research interests lie in the areas of public utility productivity and faculty compensation.

Dr. Yu Hsing, former Head of the Department of General Business at Southeastern Louisiana University has over a decade of administrative experience. He is a prolific researcher. Much of his research interests lie in financial analysis, economic impacts of public policy, and changes in market conditions.

\section{REFERENCES}

1. Bannister, B. D. (1986). Performance outcome feedback and attributional feedback: Interactive effects on recipient responses. Journal of Applied Psychology, 71:203-210.

2. Bateman, T. S. Bateman and Snell, S. A. (2009). Management: Leading and Collaborating in the Competitive World $8^{\text {th }}$, McGraw-Hill / Irwin, New York, NY.

3. Bennett, J. B. (1985). Periodic evaluation of tenured faculty performance. New Directions for Higher Education, 49:65-73.

4. Bennett, J. B. and Chater, S.S. (1984). Evaluating the performance of tenured faculty members. Educational Record, 65: 38-41.

5. Daft, R. L. (2005). Management $7^{\text {th. }}$ Thomson / Southwestern, Mason, Ohio.

6. $\quad$ Fulk., J., Brief, A.P., and Barr, S. H. (1985). Trust-in-supervisor and perceived fairness and accuracy of performance evaluations. Journal of Business Research, 13:299-313.

7. George, J. M. and Jones, G. R. (2005). Understanding and Managing Organizational Behavior $4^{\text {th }}$, Pearson / Prentice Hall, Upper Saddle River, New Jersey.

8. Goodson, J. R., Duarte, N. T. \& Budden, M. C. (1995, Fall). What gives you the right to tell me? The demotivating effects of feedback as a function of source credibility. Journal of Business and Society, 8(2), 151-162.

9. Greenberg, J. (1986). Determinants of perceived fairness of performance evaluations. Journal of Applied Psychology, 71:340-342.

10. Ilgen, D.R., Fisher, C.D. and Taylor, M.S. (1979). Consequences of individual feedback on behavior in organizations. Journal of Applied Psychology, 64: 349-371.

11. Ilgen, D.R., Peterson, R.B., Martin, B.A., and Boeschen, D.A. (1981). Supervisor and subordinate reactions to performance appraisal sessions. Organizational Behavior and Human Performance, 28: 311330.

12. Landy, F.J., Barnes, J.L., and Murphy, K.R. (1978). Correlates of perceived fairness and accuracy of performance evaluation. Journal of Applied Psychology, 63: 751-754.

13. Larson, Jr. J.R. (1984). The performance feedback process: A preliminary model. Organizational Behavior and Human Performance, 33: 42-76.

14. Lussier, R. N. (2006) Management Fundamentals $3^{\text {rd }}$, Thomson / Southwestern, Mason, Ohio.

15. Mathis, R.L. and Jackson, J. H. (2006). Human Resource Management, 11 ${ }^{\text {th }}$, Thomson / Southwestern, Mason Ohio.

16. Reisman, B. (1986). Performance evaluation for tenured faculty: Issues and research. Liberal Education, 72: 73-87.

17. Williams, C. (2007). Management $4^{\text {th }}$ (2007). Thomson / Southwestern, Mason, Ohio. 
NOTES 